\title{
Retinoblastoma protein positively regulates terminal adipocyte differentiation through direct interaction with C/EBPs
}

\author{
Phang-Lang Chen, Daniel J. Riley, Yumay Chen, and Wen-Hwa Lee ${ }^{1}$ \\ Center for Molecular Medicine, Institute of Biotechnology, The University of Texas Health Science Center at San Antonio, \\ San Antonio, Texas 78245 USA
}

To define a mechanism by which retinoblastoma protein $(\mathbf{R b})$ functions in cellular differentiation, we studied primary fibroblasts from the lung buds of wild-type $\left(R B^{+1+}\right)$ and null-mutant $\left(R B^{-1-}\right)$ mouse embryos. In culture, the $\boldsymbol{R B}^{+/+}$fibroblasts differentiated into fat-storing cells, either spontaneously or in response to hormonal induction; otherwise syngenic $R B^{-1-}$ fibroblasts cultured in identical conditions did not. Ectopic expression of normal $\mathrm{Rb}$, but not $\mathrm{Rb}$ with a single point mutation, enabled $R^{-/-}$fibroblasts to differentiate into adipocytes. $\mathrm{Rb}$ appears in murine fibroblasts to activate CCAAT/enhancer-binding proteins (C/EBPs), a family of transcription factors crucial for adipocyte differentiation. Physical interaction between $\mathrm{Rb}$ and C/EBPs was demonstrated by reciprocal coimmunoprecipitation, but occurred only in differentiating cells. Wild-type $R b$ also enhanced the binding of C/EBP to cognate DNA sequences in vitro and the transactivation of a C/EBPß-responsive promoter in cells. Taken together, these observations establish a direct and positive role for $\mathbf{R b}$ in terminal differentiation. Such a role contrasts with the function of $\mathbf{R b}$ in arresting cell cycle progression in $G_{1}$ by negative regulation of other transcription factors like E2F-1.

[Key Words: C/EBP; transcription factors; cell cycle; adipocyte differentiation; tumor suppressor protein]

Received July 18, 1996; revised version accepted September 5, 1996.

Functions of the tumor suppressor protein $\mathrm{Rb}$ have been explored in many systems. $\mathrm{Rb}$ is fundamental in suppressing the formation of certain neoplasms, because all retinoblastomas and many other tumors harbor important $R B$ gene mutations. Considerable evidence is accumulating to show that $\mathrm{Rb}$ is also involved in pathways of growth and differentiation in normal cells (Riley et al. 1994; Chen et al. 1995a). The protein is crucial for example in development, as determined from studies of mice in which $\mathrm{Rb}$ has been inactivated in the germ-line. $R B^{-1-}$ mice die during mid- to late gestation, at a stage when many highly specialized cell types begin to form. At the time of their demise at gestational day 14.5, the fetuses have significant abnormalities in neuronal and hematopoietic development: Certain neurons and erythrocyte precursors fail to exit the cell cycle and continue to divide in aberrant locations (Jacks et al. 1992; Lee et al. 1992). Moreover, some nondividing cells also fail to differentiate terminally, whereas others undergo unscheduled apoptosis (Lee et al. 1992; 1994).

Cells that express no functional $\mathrm{Rb}$ cycle faster and more autonomously than normal cells. In human tumor

${ }^{1}$ Corresponding author. cells expressing only mutated $\mathrm{Rb}$, expression of normal $\mathrm{Rb}$ suppresses the cells' neoplastic phenotypes, including tumorigenicity in nude mice (Huang et al. 1988; Bookstein et al. 1990). Furthermore, in both RB-deficient and normal cells, $\mathrm{Rb}$ has been shown to be a gatekeeper for entry into $S$ phase of the cell division cycle (Goodrich et al. 1991). Taken together, the observations in human tumors, experimental animals, and cultured cells demonstrate the importance of $\mathrm{Rb}$ in cell differentiation, as well as in regulating cell cycle progression and tumorigenesis.

Many of the functions of $\mathrm{Rb}$ depend on association with other proteins at crucial phases in the life of the cell. The identification of Rb-associated proteins has shed considerable light on the molecular pathways involved in the deregulated growth characteristic of cells with inactivated $\mathrm{Rb}$. Several viral oncoproteins, including simian virus 40 large $\mathrm{T}$ antigen and adenovirus E1A, have been found to bind strongly to hypophosphorylated $\mathrm{Rb}$ (DeCaprio et al. 1988; Whyte et al. 1988). By binding to strategic domains they functionally inactivate $R b$, probably by displacing cellular proteins important for normal functions in negative cell cycle regulation. A key cellular protein with which $\mathrm{Rb}$ associates is one of the transcription factors known as E2F (Nevins 1992). Rb is 
known to inactivate E2F-1, which plays a critical role in promoting S phase entry (Johnson et al. 1993; Shan and Lee 1994). For example, expression of excess E2F-1 in $G_{1}$ phase initiates premature $S$ phase entry and leads to unscheduled apoptosis (Shan and Lee 1994). In normally cycling cells, phosphorylation of $\mathrm{Rb}$ serves to release free E2F-1, and thereby to allow progression to committed phases of the cell cycle (Nevins 1992).

Although the molecular mechanisms by which the retinoblastoma protein functions to restrict passage past $\mathrm{G}_{1}$ phase of the cell cycle have been reported extensively (Riley et al. 1994), the functions of Rb in cellular differentiation have only begun to be explored. Correlative evidence suggests that $\mathrm{Rb}$ is important in mice for muscle differentiation in culture (Gu et al. 1993) and neuronal differentiation (Lee et al. 1994). However, the more precise molecular roles of $\mathrm{Rb}$ in differentiation have remained elusive. In the course of establishing embryonic lung fibroblasts from $\mathrm{Rb}$-deficient mice, we discovered that $R B^{+1+}$ cells could be induced to differentiate into adipocytes whereas otherwise equivalent $R B^{-1-}$ fibroblasts could not. These primary fibroblasts thus closely resemble the well-studied 3T3-L1 preadipocyte cell line and are therefore suitable for addressing in depth the potential roles of $\mathrm{Rb}$ in adipocyte differentiation. The differentiation of preadipocytes is known to involve a group of transcription factors, CCAAT/enhancer-binding proteins (C/EBPs) (McKnight et al. 1989; Cao et al. 1991; Samuelsson et al. 1991; Umek et al. 1991), that transactivate the promoters of several adipocyte-specific genes, including the fatty acid-binding protein 422 /aP2 (Christy et al. 1989; 1991). In this communication, we show that $\mathrm{Rb}$ directly interacts with and activates $\mathrm{C} / \mathrm{EBPs}$ to regulate the transcription of genes involved in adipocyte differentiation.

\section{Results}

Normal embryonic fibroblasts differentiate into adipocytes but Rb-deficient cells do not

Embryonic lung fibroblasts (ELFs) were prepared from postcoital day 14.5 C57BL/6J/129Sv mouse embryo lung buds, and checked by a PCR method for the presence of wild-type or mutant $R B$ genes (Fig. 1B). These cells were subsequently cultured in DME medium supplemented with $10 \%$ fetal bovine serum until density arrested. Medium was changed periodically but the cells were not further passaged. When confluent for $4-6$ weeks, $R B^{+/+}$ (ELF1) cells spontaneously differentiated to a fat-laden phenotype but $R B^{-1-}$ (ELF7) cells derived from an embryo in the same litter did not (Fig. 1A,B). Characteristic fat droplets in the cytoplasm stained with Oil Red EGN and marked the adipogenic phenotype. With a reliable hormone induction protocol established for 3T3-L1 murine preadipocytes (Green and Kehinde 1974; Student et al. 1980), $R B^{+/+}$ELF1 cells could be induced to differentiate much like 3T3-L1 cells into fat-laden cells after 8

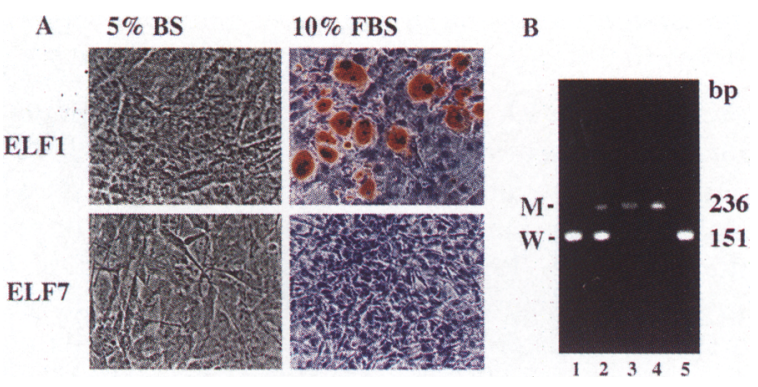

Figure 1. Spontaneous differentiation of murine embryonic fibroblasts into adipogenic cells. Primary fibroblasts lines ELF1 $\left(R B^{+1+}\right)$ or ELF7 $\left(R B^{-1-}\right)$ were cultured in DMEM with either $5 \%$ bovine serum (BS) or $10 \%$ fetal bovine serum (FBS). The cultures were allowed to be confluent for 4 weeks with medium changes twice weekly. (A) Photomicrographs under plane-polarized light (left) show the morphology of fibroblasts when maintained quiescent in 5\% BS and when cultured in 10\% FBS but contact inhibited. The panels on the right show the cells maintained in $10 \%$ FBS and stained with Oil Red EGN and hematoxylin to show the accumulation of fat droplets. $(B)$ Genotyping for $R B$ by a PCR method. A 151-bp fragment is derived from wild-type $R B$ genomic DNA (W) and the 236-bp fragment from mutated $R B^{\Delta 20}$ DNA (M) (Nikitin and Lee 1996). (Lanes 1-3) Controls: genomic DNA extracted from tail biopsies of mice with the genotypes $R B^{+1+}, R B^{+1-}$, and $R B^{-1-}$; (lane 4) ELF7; (lane 5) ELF1.

days, but similarly treated $R B^{-1-}$ ELF7 cells could not (Fig. 2). From these observations we conclude that $R B-$ null fibroblasts cannot differentiate in culture to the adipogenic phenotype, either spontaneously or in response to appropriate hormonal stimuli.

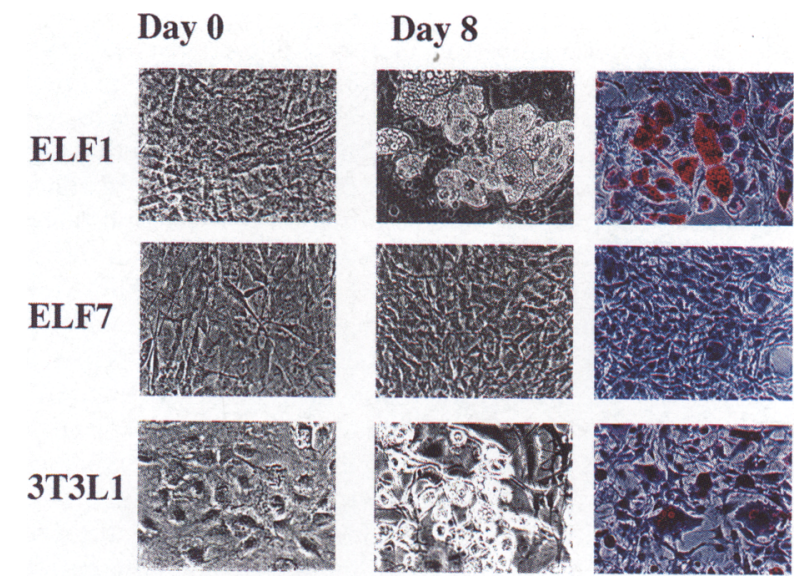

Figure 2. Adipocyte differentiation of ELF1 and 3T3-L1 cells after hormone treatment. Mouse fibroblasts lines ELF1, ELF7, and 3T3-L1 were induced with hormones for 8 days following the treatment protocol described in Materials and Methods. The morphologies of each cell line before and after hormonal induction are shown. The left and middle panels are photomicrographs taken under plane-polarized light. At day 8 after induction of differentiation, cells were stained with Oil Red EGN and counterstained with hematoxylin (right panels). 
Expression of wild-type $\mathrm{Rb}$ in $\mathrm{RB}^{-1-}$ fibroblasts restores their ability to differentiate into adipocytes

To test whether $\mathrm{Rb}$ expression is the key factor in determining the potential of embryonic lung fibroblasts to differentiate into fat-laden cells, $R B^{-1-}$ fibroblasts were transfected with plasmids containing wild-type or point mutant $\left(\mathrm{Cys}^{706} \rightarrow\right.$ Phe, Bignon et al. 1990) $R B$ cDNA to express either $\mathrm{Rb}$ protein. Both wild-type and mutant $\mathrm{Rb}$ proteins were expressed in the appropriate cells after transfection (Fig. 3B). The fibroblasts transfected with the plasmid expressing wild-type $\mathrm{Rb}$ differentiated into fat-laden cells in response to hormonal treatment (Fig. 3A). In contrast, untransfected fibroblasts and those transfected with mutant $R B$ failed to differentiate along the same lineage (Fig. 3A). Eight hygromycin-resistant colonies from a bulk population of ELF7 fibroblasts transfected with wild-type $R B$ were tested individually for expression of $\mathrm{Rb}$ protein and for their potential to

A
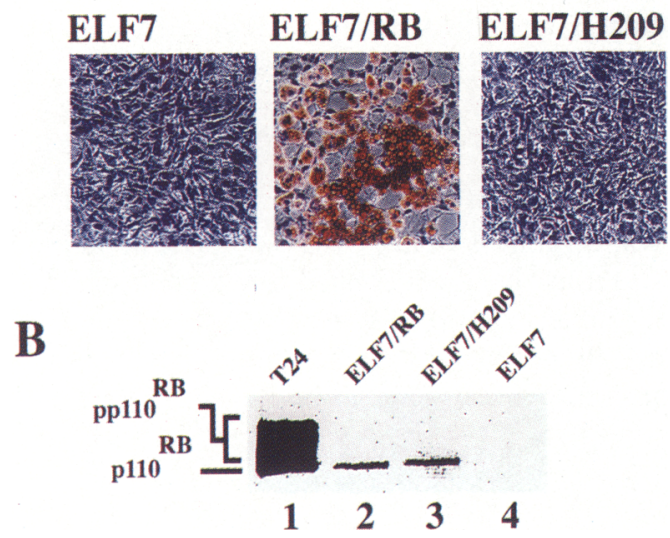

Figure 3. Ectopic expression of the wild-type but not point mutated $\mathrm{Rb}$ in $R B^{-1-}$ ELF7 cells restores the capacity to differentiate. ELF7 cells were cotransfected with two plasmids, one which expresses the wild-type $\mathrm{Rb}$ under the tetracycline-controllable promoter, and one which expresses the tet regulator along with a hygromycin selection marker (Gossen and Bujard 1992). The $\mathrm{H} 209$ mutant $\mathrm{Rb}$ expression was similarly driven by a tetracycline-inducible promoter. Low-level expression from this leaky promoter in the presence of tetracycline supplied detectable $\mathrm{Rb}$ but did not arrest cell growth. After selection with hygromycin, the transfected cells were grown to confluence and subjected to the hormonal treatment protocol previously described. (A) Photomicrographs show the morphological changes in ELF7 cells transfected with the wild-type RB: They acquire the adipogenic phenotype. Identical cells untransfected or transfected with the $\mathrm{H} 209$ mutant RB do not differentiate similarly. $(B) \mathrm{Rb}$ protein is expressed in cells transfected with both wild-type and mutant RB constructs. Lysates of the transfected cells were immunoprecipitated with an anti-Rb $\mathrm{mAb}$ (11D7), separated by SDS-PAGE, transferred to membranes, and probed with the same antibody. Cycling T24 cells (lane 1) serve as a control for the positions at which hypo- and hyperphosphorylated Rb species migrate. Expression of both wild-type (lane 2) and mutant $\mathrm{Rb}$ (lane 3) was apparent in both populations of transfected cells, but not in untransfected cells (lane 4).

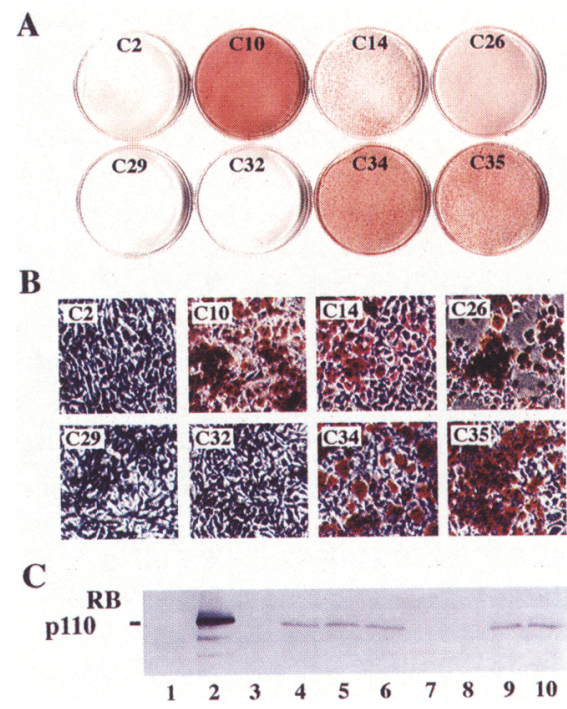

Figure 4. Differentiation of ELF7 clones into adipocytes depends on the expression of $\mathrm{Rb}$ protein. Eight hygromycin resistant clones were propagated until confluent, and treated with the hormone combination described previously. (A) Entire populations of cells in 60-mm plates were first stained with Oil Red EGN. $(B)$ The cells were then counterstained with hematoxylin and photomicrographs were taken from random sections of the plates in $A$. Clones $\mathrm{C10}, \mathrm{Cl} 4, \mathrm{C} 26, \mathrm{C} 34$, and C35 differentiated into adipocytes as described for Fig. 3. (C) Expression of $\mathrm{Rb}$ detected by immunoprecipitation and Western blotting. Only clones expressing $\mathrm{Rb}$ differentiated in response to hormonal induction. (Lane 1) Untransfected ELF7 cells; (lane 2) T24 bladder carcinoma cells (growth arrested and expressing predominantly hypophosphorylated $\mathrm{Rb}$ ) as a positive control for the position of p1 10 $0^{\mathrm{RB}}$; (lane 3) clone 2 (C2); (lane 4) C10; (lane 5) C14; (lane 6) C26; (lane 7) C29; (lane 8) C32; (lane 9) C34; (lane 10) C35.

differentiate into fat-storing cells with hormone treatment. Only those clones expressing Rb gained the ability to differentiate; those that failed to express $\mathrm{Rb}$ also failed to acquire the adipogenic phenotype (Fig. 4). To test whether the cells rescued by $R b$ and differentiated by hormone treatment were adipocytes, we examined them for expression of the fatty acid-binding protein $422 / \mathrm{aP} 2$ (Christy et al. 1991). 422/aP2 messenger RNA was detected in all fat-laden cells that expressed $R b$, but not in undifferentiated fibroblasts without functional $\mathrm{Rb}$ (Fig. 5). Taken together, these results suggest that $\mathrm{Rb}$ is a critical factor for the differentiation of embryonic lung fibroblasts into fat-storing cells.

\section{$R b$ and $C / E B P s$ interact in vitro}

Previous studies have shown convincingly that expression of CCAAT/enhancer-binding protein transcription factors sequentially activates terminal adipocyte differentiation (Cao et al. 1991; Yeh et al. 1995). In particular $\mathrm{C} / \mathrm{EBP} \alpha$ directly regulates terminal adipocyte differentiation by turning on a battery of genes required for the synthesis, uptake, and storage of long-chain fatty acids (Samuelsson et al. 1991; Umek et al. 1991; Freytag et al. 


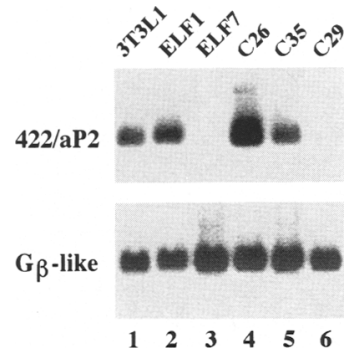

Figure 5. 422/aP2 mRNA expression in morphologically differentiated adipocytes. 3T3-L1, ELF1, ELF7, and three ELF7 clones transfected with RB were treated with the hormone induction protocol for 8 days, after which RNA was extracted from each individual line. Ten $\mu \mathrm{g}$ of total RNA were analyzed and probed with $422 / \mathrm{aP} 2 \mathrm{cDNA}$ or with $\mathrm{G} \beta$-like protein $\mathrm{CDNA}$. Only those lines that expressed Rb (3T3-L1, ELF1, C26, and C35) also expressed 422/aP2 mRNA.

1994; Lin and Lane 1994). C/EBP 8 and $\beta$ appear to play earlier, catalytic roles in the differentiation pathway by relaying hormonal and other events, leading to activation of C/EBP $\alpha$ (Yeh et al. 1995). To begin to address how $\mathrm{Rb}$ influences adipocyte differentiation, the interaction between $\mathrm{Rb}$ and C/EBPs was examined in vitro. The $\mathrm{cD}$ NAs encoding C/EBP $\alpha, \beta$, and $\delta$ were each individually inserted into glutathione $S$-transferase (GST) expression plasmids and the resultant fusion proteins were expressed in bacteria. In the case of C/EBP $\beta$, we took advantage of a specific $\mathrm{NcOI}$ site at codon 22 (see Materials and Methods) to create a construct that would preferentially produce the transcriptionally active form of C/EBP $\beta$, termed liver-enriched transcriptional activator protein (LAP), rather than the smaller, inactive form, termed liver-enriched transcriptional inhibitory protein (LIP) (Descombe and Schibler 1991).

All three GST-C/EBP fusion proteins bound specifically to the hypophosphorylated isoform of $\mathrm{Rb}$, the ac- tive form that predominates in the $G_{0}$ and $G_{1}$ phases of the cell cycle (Fig. 6A). GST-SV40 T antigen also bound $\mathrm{Rb}$, but GST alone did not. To determine which region of $\mathrm{Rb}$ is required for binding to LAP, various $\mathrm{Rb}$-deletion mutant proteins were expressed using the pET system (Shan et al. 1992). By passing the bacterial lysates over GST-LAP or GST-SV40 T antigen fusion protein columns, we determined that the same two domains required for binding $\mathrm{T}$ antigen (Hu et al. 1990; Huang et al. 1990) are also required for Rb to bind to LAP (Fig. 6B,C). The interaction of LAP with $\mathrm{Rb}$ may occur in a manner similar to that used by the nuclear factor-interleukin 6 (NF-IL6) (P.-L.Chen et al. 1996), because a sequence in C/EBP $\beta$, from amino acids 66 to 102, is nearly identical to NF-IL6 amino acids 78 to 122 . Similar critical residues also were found in C/EBPo and C/EBP $\delta$, as well as in the Rb-binding region of E2F-1 (Shan et al. 1996), as shown in Fig. 6D. This sequence conservation is consistent with the results from in vitro binding assays.

\section{$R b$ and $C / E B P$ s interact in terminally differentiating cells}

Having established an interaction between $\mathrm{Rb}$ and C/EBPs in vitro, we next explored the interaction in cells during terminal differentiation. In these experiments, $R B^{+1+}$ ELF1 cells were again employed, for they could be reliably and synchronously differentiated into adipocytes by hormonal treatment. At intervals after the beginning of induction of adipocyte differentiation, the interaction between $\mathrm{Rb}$ and $\mathrm{C} / \mathrm{EBP} \beta$ (as an example for other C/EBPs) was examined by coimmunoprecipitation. In quiescent $R B^{+1+}$ ELF1 cells, expression of both $\mathrm{C} / \mathrm{EBP} \beta$ and hypophosphorylated $\mathrm{Rb}$ was observed (Fig. 7, lane 6), and the cells were subsequently able to differentiate into adipocytes. Attempts to induce adipocyte differentiation in $R B^{-1-}$ ELF7 cells were unsuccessful, despite the presence and relative abundance of C/EBP $\beta$
A
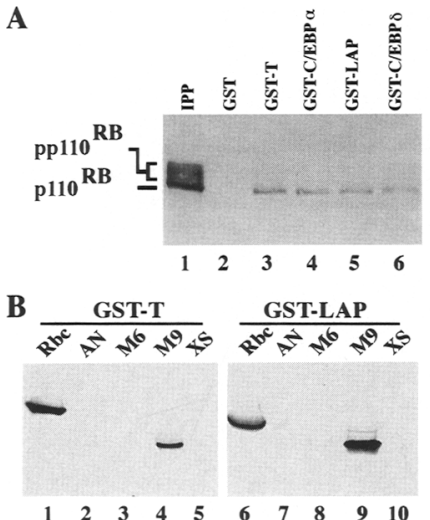

$\begin{array}{llllllllll}1 & 2 & 3 & 4 & 5 & 6 & 7 & 8 & 9 & 10\end{array}$
C

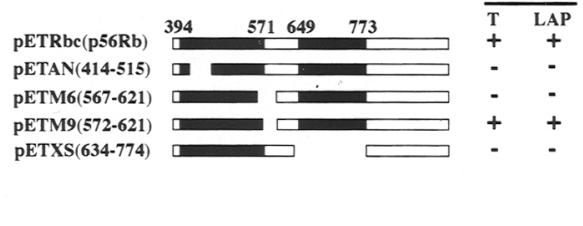

D

Y HFGLEEG E GIR DLF E2F1

$Y$ IDPAAFND E FLA DLF C/EBP $\alpha$ $Y$ LEPLAPAAADFAAPAPAHH D FLS DLF C/EBP $\beta$ $Y$ IDSMAAVPTLELCHD E LFA DLF C/EBPS Y LEPLGAPQAPAPATATDTFEAAPPAPAPAPASSGQHH D FLS DLF NF-IL6

$$
Y\left(X_{7-37}\right) D / E\left(X_{3}\right) D L F
$$

Figure 6. Hypophosphorylated $\mathrm{Rb}$ protein binds specifically to C/EBPs in vitro through an SV40 large $\mathrm{T}$ antigen binding domain. (A) GST, GST-T, or GST-C/EBP $\alpha$, GST-LAP (GST-C/ EBP $\mid$, and GST-C/EBPS fusion proteins immobilized on glutathione beads were used to bind $\mathrm{Rb}$ in $R B$-reconstituted (WR2E3) cell lysates. Lane 1 shows both hypo- and hyperphosphorylated forms of $\mathrm{Rb}$ protein immunoprecipitated (IPP) with anti-Rb antibody $11 \mathrm{D} 7$ in cycling cells. Similar cell extracts were incubated with beads containing various GST fusion proteins (lanes 2-6). The three forms of GST-C/ EBP specifically bound hypophosphorylated $\mathrm{Rb}$ (lanes 4-6), as did the positive control, GSTSV40 $\mathrm{T}$ antigen (lane 3). (B) Both wild-type and

a series of mutant $\mathrm{Rb}$ proteins, as shown in $C$, were used to bind beads containing either GST-T (lanes 1-5) or GST-LAP (lanes 6-10). The proteins bound to the beads were then released, separated by SDS-PAGE, and detected with antibody 11D7, as described above. (C) The binding sites for C/EBP in Rb protein are similar to those used by the SV40 T antigen. The shaded areas represent the A and $\mathrm{B}$ regions of T-antigen binding domain. $(D)$ Comparison revealed sequence homology in the Rb-binding motifs of C/EBP proteins with those of NF-IL6 (from residues 105 to 128) and E2F-1 (from residues 411 to 425). The consensus motif is shown. 
Chen et al.

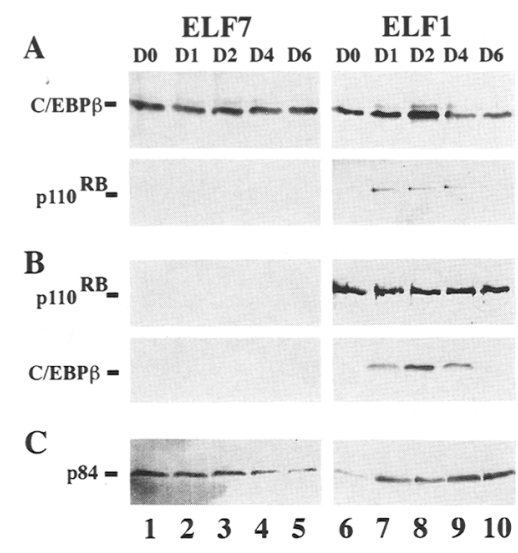

Figure 7. Interaction of $\mathrm{Rb}$ with $\mathrm{C} / \mathrm{EBP} \beta$ occurs specifically when ELFl cells differentiate into adipocytes. $|A| R B^{-1-}$ ELF7 and $R B^{+1+}$ ELFl cells were treated with the aforementioned hormone protocol for 6 days. Cells lysates were prepared at different time points for reciprocal coimmunoprecipitations with anti-C/EBP $\beta$ antibody $\mathrm{C}-19(A)$ or anti-Rb antibody 0.47 $(B) \mathrm{D} 0$ is day zero with respect to the beginning of hormone induction, D2 is day two, etc. Immunoprecipitated proteins were separated by SDS-PAGE, transferred to Immobilon-P, and immunoblotted with either 0.47 antibody for $\mathrm{Rb}$ or $\mathrm{C}-19$ for $\mathrm{C} / \mathrm{EBP} \beta$, as indicated. $\mathrm{p} 84$, a protein expressed constitutively and constantly during differentiation (Durfee et al. 1994), was used as an internal standard to control for cell lysate loading $(C)$.

(Fig. 7A, lanes 1-5). In contrast, hormonal treatment of $R B^{+1+}$ ELFl cells resulted in acquisition of the morphologic characteristics of mature adipocytes. Concomitant with this differentiation, $\mathrm{C} / \mathrm{EBP} \beta$ expression was slightly increased by day 2 , and a definite interaction between C/EBP $\beta$ and the hypophosphorylated form of $\mathrm{Rb}$ was detected by coimmunoprecipitation (Fig. 7, lanes 7-9). By day 6 after hormone induction, the interaction between C/EBP $\beta$ and $\mathrm{Rb}$ was no longer evident (lane 10). $\mathrm{Rb}$ protein could not be detected by coimmunoprecipitation in $R B^{-1-}$ ELF7 cells, because any Rb protein produced in these cells is truncated and nonfunctional (Lee et al. 1992) (Fig. 7B, lanes 1-5). Note that the coimmunoprecipitations were not attributable to antibody crossreactivity, because antibodies to $\mathrm{C} / \mathrm{EBP} \beta$ epitopes did not recognize $\mathrm{Rb}$ (Fig. 7A) and antibodies to $\mathrm{Rb}$ epitopes did not recognize C/EBP (Fig. 7B). Like the interaction between $\mathrm{Rb}$ and $\mathrm{C} / \mathrm{EBP} \beta$, binding between $\mathrm{Rb}$ and $\mathrm{C} / \mathrm{EBP} \alpha$ could also be demonstrated by coimmunoprecipitation during the terminal differentiation of ELFl cells to adipocytes (data not shown).

\section{$R b$ enhances the binding of LAP to specific DNA}

The consequence of $\mathrm{Rb}$ binding to C/EBPs cannot be attributed to a negative role in inactivation of C/EBPs, because the expression of C/EBPs actually activates the adipogenic differentiation process in a sequential cascade (Cao et al. 1991; Samuelsson et al. 1991; Yeh et al. 1995). To address the influence of $\mathrm{Rb}$ on the DNA-binding activity of a C/EBP in vitro and to compare it with the established role of $\mathrm{Rb}$ in regulating another wellcharacterized transcription factor, a DNA electrophoretic mobility shift assay (EMSA) was designed specifically for LAP and for E2F-1. The latter protein is known to be inactivated when $\mathrm{Rb}$ prevents progression of the cell cycle to S phase (Nevins 1992). The DNA probe (E2F100) used in our assay contains both LAP and E2F-1-responsive sequences (P.-L. Chen et al. 1996), and forms complexes with either LAP or E2F-1. As expected, bacterially expressed GST-LAP specifically recognized the appropriate DNA sequence and retarded the migration of a labeled DNA probe (Fig. 8A, lane 2). However, addition of purified, amino-terminally truncated p56 ${ }^{\mathrm{RB}}$, which still has intact $\mathrm{T}$ antigen, NF-IL6, and C/EBP-binding domains (Hensey et al. 1994; P.-L. Chen et al. 1996), increased by $>10$-fold the binding of LAP to its recognition sequences, in an $\mathrm{Rb}$ dose-dependent manner (Fig. $8 \mathrm{~A}$, lanes 5-91. In contrast, the binding of E2F-1 to the same DNA probe was either unaffected or actually decreased by $\mathrm{Rb}$ (Fig. $8 \mathrm{~B}$ ). $\mathrm{Rb}$ thus had opposite effects on the DNA-binding activity of two important transcription factors.

Physical interaction with $\mathrm{Rb}$ is a prerequisite for the DNA-binding activity of LAP to be enhanced. A pointmutated $\mathrm{Rb}\left(\mathrm{H} 209\right.$, Cys ${ }^{706} \rightarrow$ Phe) (Bignon et al. 1990), which cannot bind C/EBPs, did not enhance the binding of LAP to DNA in the same assay (Fig. $8 \mathrm{C}$ ). To determine whether $\mathrm{Rb}$ protein was present in the LAP-DNA complexes, three anti-Rb antibodies, 3C8 (Lee et al. 1992), 11D7 (Shan et al. 1992), and 0.47 (Huang et al. 1990), which recognize three distinct epitopes, were added individually to the EMSA. None of the antibodies had any effect on the mobility of the LAP-DNA complexes (Fig. $8 \mathrm{D}$, lanes 9-11). This observation indicates that $\mathrm{Rb}$ is not present continuously or stably in complexes with LAP and sequence-specific DNA. The presence of LAP in complexes with DNA, however, was demonstrated by supershift with an anti-C/EBP / LAP antibody (Fig. 8D, lane 12). The specificity of the antibodies was confirmed by inability of anti- $T$ antigen antiserum to supershift the protein-DNA complex (Fig. 8D, lane 13). Moreover, the effect of Rb on the DNA-binding activity of LAP was not particular to the amino-terminally truncated $\mathrm{p} 56^{\mathrm{RB}}$, because full-length $\mathrm{p} 110^{\mathrm{RB}}$, purified from the pET system or from a baculovirus expression system, also enhanced the binding of LAP to specific DNA sequences/data not shown).

\section{$R b$ enhances transactivation by $C / E B P$ in transient transfection assays}

To explore the functional significance of the interaction between $\mathrm{Rb}$ and $\mathrm{C} / \mathrm{EBPs}$, the effect of $\mathrm{Rb}$ expression on transcriptional activation by LAP was examined. The chloramphenicol acetyl transferase reporter construct $\left[\mathrm{pP}_{(\mathrm{D}) 9} \mathrm{CAT}\right]$ (Mueller et al. 1990), which is regulated specifically by LAP, was used for testing the effect of Rb on adipocyte-specific gene expression. Human retinoblastoma WERI-Rb27 cells, which do not express functional $\mathrm{Rb}$, were chosen as the recipient cells because they pro- 


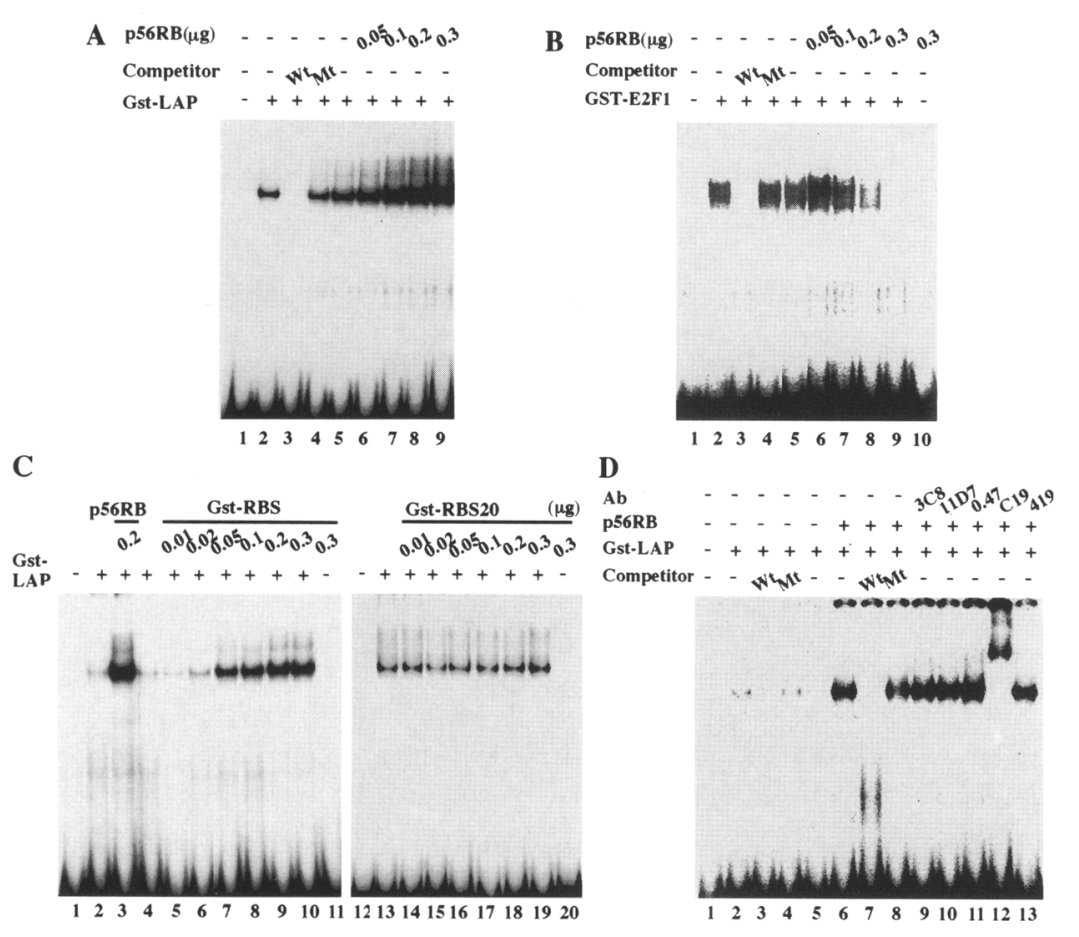

Figure 8. Rb enhances binding of the transcription factor LAP to DNA-containing LAP recognition sequences. (A) E2F100, an oligonucleotide which contains consensus sequences with which both LAP and E2F-1 interact specifically, was labeled with ${ }^{32} \mathrm{P}$ and served as probe. Bacterially expressed GST-LAP was added into the EMSA and retarded the mobility of E2F100 (lane 2). Upon addition of excess of unlabeled oligo DNA containing the wild-type recognition sequence of LAP (Wt, lane 3) as a competitor, the binding of E2F100 was abolished (lane 3). Upon the addition of mutant oligo DNA, which LAP cannot recognize, the binding of E2F100 by GST-LAP was not changed (lane 4). Increasing concentrations of purified $\mathrm{p} 56^{\mathrm{RB}}$ protein enhanced binding to E2F100 in a dose-dependent manner, ultimately by more than 10 -fold when present at a dose of $0.3 \mu \mathrm{g}$ (lane 9). (B) A similar experiment demonstrates that $\mathrm{Rb}$ inhibits binding to the same E2F100 oligonucleotide to E2F-1. Wild-type and mutant E2F-1 oligo DNA were used to demonstrate the binding specificity of E2F-1 (lanes 1-4). Upon addition of increasing amounts of purified p56 $6^{\mathrm{RB}}$ to the EMSA, the binding of E2F-1 to E2F100 was reduced or abolished (lanes 6-9). Equivalent amounts of the fusion proteins ( $50 \mathrm{ng} /$ lane) GST-LAP $(A)$ and GST-E2F-1 (B) were added for each mobility shift assay. $(C)$ Enhancement of the binding of GST-LAP to its DNA sequence is specific for wild-type p56 $6^{\mathrm{RB}}$ (GST-RBS, lanes 5-10) but not mutated p56 $6^{\mathrm{RB}}$ (GST-RBH209, lanes 13-19). Instead of the purified $\mathrm{p} 56^{\mathrm{RB}}$ protein, GST fusion proteins with the wild-type p56 ${ }^{\mathrm{RB}}$ (GST-RBS) and the corresponding point

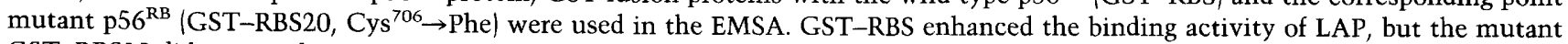
GST-RBS20 did not. Each reaction contains $50 \mathrm{ng}$ of GST-LAP. Alone, neither GST-RBS (lane 11) nor GST-RBS20 (lane 20 ) bind to the probe. $(D) \mathrm{Rb}$ is not present in the DNA-LAP protein complex. In this set of experiments, 50 ng of GST-LAP was added to each reaction. The binding to DNA of the activated LAP could be abolished by competition with wild-type but not mutant oligo DNA (lanes 7 and 8$)$. This suggests that activated LAP binds specifically to its cognate sequences, as it does even before activation by p56 $6^{\mathrm{RB}}$ (lane 2). Various anti-Rb antibodies $(3 \mathrm{C} 8,11 \mathrm{D} 7,0.47$, lanes 9-11) and a nonspecific, anti-T antigen antibody (419) (lane 13) had no effect on the mobility of these complexes. A supershift was detected, however, when antibody C-19, which recognizes LAP, was added (lane 12).

vide a background on which the effects of $\mathrm{Rb}$ expression can be measured. As shown in Fig. 9, LAP alone increased CAT activity 10-fold compared with vector alone (lane 2). Coexpression of LAP and Rb in Rb-null cells, however, synergistically increased CAT activity almost 40-fold (lane 4). When compared with LAP expression alone, coexpression of the $\mathrm{H} 209 \mathrm{Rb}$ mutant with LAP (lane 4) had no significant additional effect on basal CAT activity. Furthermore, expression of $\mathrm{Rb}$ itself, either wild-type (lane 5) or the H209 mutant (lane 6) had no effect on CAT activity. These results demonstrate that wild-type $\mathrm{Rb}$, in addition to increasing the DNAbinding activity of LAP in vitro, can also enhance the transcriptional activity of LAP in intact cells. A mutant $\mathrm{Rb}$ protein that did not interact with LAP also failed to enhance specific transcriptional activity.

\section{Discussion}

We have demonstrated that wild-type retinoblastoma protein is essential for mouse embryonic lung fibroblasts to differentiate into adipocytes. Without $R b$, syngenic fibroblasts fail to undergo terminal differentiation despite hormonal induction. The process of adipocyte dif- ferentiation is regulated by the interaction between $\mathrm{Rb}$, through its SV40 $\mathrm{T}$ antigen-binding domains, and the family of transcription factors known as C/EBPs. The interaction occurs in certain preadipocytes precisely when they begin to differentiate. Furthermore, $\mathrm{Rb}$ appears to activate C/EBP $\beta /$ LAP directly by enhancing its binding to cognate DNA sequences. Taken together, these observations suggest a function for $\mathrm{Rb}$ that has only begun to be explored: In addition to negatively regulating transcription factors like E2F-1 to prevent quiescent cells from passing a restriction point in $G_{1}$, it positively regulates transcription factors important for differentiation.

The development of distinct cell types from multipotent precursors can be viewed as a two-step process. In the first step, termed commitment or determination, the stem cell becomes limited to one particular lineage. In the second step, terminal differentiation, the cell develops along its determined lineage to become a functional specialized cell such as an adipocyte (Sager and Kovac 1982). $\mathrm{Rb}$ is not required in general for all steps in the differentiation of every cell type. In $R B$-deficient embryos by the time of their demise in utero, certain cells have already substantially committed to terminal differ- 
Chen et al.

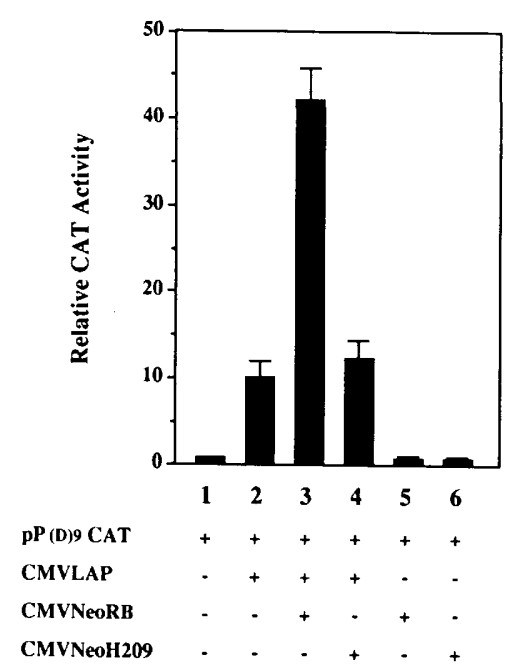

Figure 9. $\mathrm{Rb}$ activates $\mathrm{C} / \mathrm{EBP} \beta$ in transcription of a specific promoter. $R B^{-1-}$ human retinoblastoma WERI-Rb27 cells were transfected with one or more of four DNA constructs: 20 $\mu \mathrm{g}$ of the a C/EBP $\beta$-specific promoter driving the CAT reporter $\left[\mathrm{pP}_{(\mathrm{D}) 9} \mathrm{CAT}\right]$ (lanes $\left.1-6\right) ; 20 \mu \mathrm{g}$ of a C/EBP $\beta$ expression construct (MSV-C/EBPß) (lanes 2-4); $4 \mu \mathrm{g}$ of the plasmid that expresses wild-type $\mathrm{Rb}$ (CMV-NeoRB) (lanes 3 and 5); and $4 \mu \mathrm{g}$ of the construct that expresses a mutant $\mathrm{Rb}(\mathrm{CMVNeoH} 209)$ that fails to bind to C/EBPB (lanes 4 and 6). The histograms represent mean CAT activities from three separate transfections. Standard error bars are shown.

entiation. For example, the formation of somites, cardiac and skeletal muscle, bone, and several other tissues has already been accomplished in $\mathrm{RB}^{-1-}$ mice by day 14.5 of embryonic development. However, clear abnormalities in the differentiated phenotypes of diverse cells types have also been observed. Erythrocytes retain their nuclei and neuronal cells in the developing hind brain and spinal ganglia fail to differentiate further into mature neurons (Lee et al. 1994). A role for the tumor suppressor protein $\mathrm{Rb}$ in normal development is consistent in many ways with the failure in terminal differentiation seen as a distinctive phenotype of cancer. The positive role of $\mathrm{Rb}$ in terminal differentiation may be critical for tumor suppression functions.

In our current study, the interaction between $\mathrm{Rb}$ and $\mathrm{C} / \mathrm{EBP} \beta$ did not take place in $R B^{+/+}$ELF1 cells before hormonal treatment. Syngenic $R B^{-/-}$ELF7 cells, despite expressing $\mathrm{C} / \mathrm{EBP}$ proteins in a similar temporal pattern, did not differentiate even when induced by appropriate hormones. These results suggest that the presence of the transcription factors that regulate adipocyte differentiation is not by itself sufficient to allow acquisition of the final adipogenic phenotype. However, it was noted that the elevated expression of C/EBP $\beta$ was observed at $\mathrm{D} 2$ after interaction with $\mathrm{Rb}(\mathrm{D} 1)$. This is consistent with the finding that $C / E B P \beta$ mRNA was induced at the beginning of adipocyte differentiation /Cao et al. 1991). Hormonal treatment may activate C/EBPs through the interaction with $\mathrm{Rb}$, and may be the major force for initiation of subsequent events in the differen- tiation cascade. Congruous findings have been reported in the differentiation of 3T3-L1 cells, although even the expression of C/EBPs in these cells was not evident until after hormonal induction (Yeh et al. 1995). The detailed downstream mechanisms by which glucocorticoids, adenylate cyclase activators, and insulin transduce signals to allow the interaction between $\mathrm{Rb}$ and C/EBPs is unknown at present, but is actively being pursued. It is likely that $\mathrm{C} / \mathrm{EBP} \beta$ and other $\mathrm{C} / \mathrm{EBPs}$ may require hormone-mediated signal transduction pathways that ultimately result in post-translational modifications or changes in subcellular compartmentalization and allow them to interact with $\mathrm{Rb}$ in vivo. In addition to C/EBPs, another transcription factor, peroxisome proliferationactivator receptor $\gamma(\operatorname{PPAR} \gamma)$, has also been shown to be directly involved in adipocyte differentiation ( $\mathrm{Hu}$ et al. 1995; Tontotoz et al. 1994a,b). Interestingly, known members of the C/EBP family not only all interact with $\mathrm{Rb}$, they each contain Rb-binding motifs similar to the one used by E2F-1. In contrast, PPAR $\gamma$, although it has no recognizable $\mathrm{Rb}$-binding motif (Tontotoz et al. 1994a), can be regulated by C/EBP (Wu et al. 1995). We therefore would not expect it to be regulated by $\mathrm{Rb}$. $\mathrm{Rb}$ probably instead acts directly on C/EBPs, which play distinct and somewhat earlier roles in the cascade of events in adipocyte differentiation.

Previous studies in ex vivo culture systems have shown that Rb may also be important for muscle differentiation by interacting with myoD (Gu et al. 1993). Early muscle development in $R B^{-1-}$ embryos, however, proceeds normally well past the stage when myoD begins to initiate muscle developmental patterns, so the significance of the interaction between myoD and $\mathrm{Rb}$ in muscle differentiation in vivo remains correlative and circumstantial. Myotube differentiation from $R B^{-1-}$ myoblasts may be mediated in part by $\mathrm{Rb}$-related proteins such as p107 (Schneider et al. 1994). In a different but analogous cell culture system, another correlation was observed between the process of monocyte-macrophage differentiation and the positive regulation of the transcription factor NF-IL6 by Rb (P.-L. Chen et al. 1996). The significance of this correlation in vivo is likewise still unknown; no immediate monocyte-macrophage precursors with the genotype $R B^{-1-}$ are currently available to test the isolated effects of $\mathrm{Rb}$ expression on macrophage differentiation. Our results in this communication, which show lack of adipocyte differentiation in $R B^{-1-}$ mouse embryonic fibroblasts unless they are reconstituted by ectopic Rb expression, go beyond correlation. They suggest clearly that functional $\mathrm{Rb}$ is critical for the terminal differentiation of certain specialized cells. Mature adipose tissues have not been observed in either wild-type or Rb-deficient mouse fetuses because the animals depend entirely on maternal energy sources and do not store fat until birth (Wang et al. 1995).

It is important to note that $\mathrm{Rb}$ itself does not bind to C/EBP-specific DNA sequences in the mobility shift assays (Fig. 8), but nonetheless does bind to C/EBPs both in vitro and in cells during the differentiation process (Fig. 7). The interaction between $\mathrm{Rb}$ and C/EBP $\beta$ molecules 
appears to have a function in allowing LAP to bind DNA, and in the transactivation of LAP target genes: The H209 $\left(\mathrm{Cys}^{706} \rightarrow \mathrm{Phe}\right) \mathrm{Rb}$ that fails to bind to LAP also fails to enhance transactivation of relevant promoters in the in vitro systems used. These observations suggest that the $\mathrm{Rb}-\mathrm{C} / \mathrm{EBP}$ interaction occurs during a defined window only in differentiating cells, as it would if $\mathrm{Rb}$ has a function akin to a molecular chaperone (Ellis and van der Vies 1991). Our experiments suggest that there may be three forms of LAP: one inactivated prior to interaction with wild-type $R b$, a second transiently complexed with $\mathrm{Rb}$ during differentiation, and a third activated after dissociation from $\mathrm{Rb}$. The precise conformational or other change by which $\mathrm{Rb}$ directly activates LAP and other C/EBPs is not yet known. An alternative explanation for the observed transience of the $\mathrm{Rb}-\mathrm{C} / \mathrm{EBP}$ interaction only in differentiating cells may be the instability of the $\mathrm{Rb}-\mathrm{C} / \mathrm{EBP}-\mathrm{DNA}$ complex during the particular conditions of the DNA electromobility shift assay. The dependence of C/EBP activation on $\mathrm{Rb}$ protein under physiological conditions remains to be defined. Nonetheless, the in vivo transfection experiments clearly show that the $\mathrm{Rb}-\mathrm{C} / \mathrm{EBP}$ interaction, demonstrated biochemically, is also important functionally, because $\mathrm{Rb}$ positively activates transcription by C/EBP $\beta / \mathrm{LAP}$.

The mechanism by which $\mathrm{Rb}$ binds to similar motifs in two different classes of proteins (C/EBPs and E2Fs) and results in two seemingly opposite functions remains unknown. $\mathrm{Rb}$ apparently functions both to prevent progression of $G_{1}$, when E2F-1 is bound and inactivated, as well as to promote differentiation when C/EBPs are bound and activated. The T-antigen-binding domain is the major region for the interaction of $\mathrm{Rb}$ with a variety of cellular proteins (Chen et al. 1995a). The motifs recognized by this domain include $\mathrm{LxCxE}$, as in SV40 T-antigen, and $\mathrm{Y}(\mathrm{x} 7-37) \mathrm{E}(\mathrm{x} 3) \mathrm{DLF}$, as in E2F-1. Binding of $\mathrm{Rb}$ to E2F-1 results in inactivation of target gene transcription, perhaps because $\mathrm{Rb}$ binds to the carboxy-terminal transactivation domain of E2F-1. The main Rb-binding motifs in C/EBPs, however, are also located within their amino-terminal transactivation domains, and the consequence of $\mathrm{Rb}$ binding to C/EBPs is nonetheless activation. This apparent contradiction cannot be resolved without further detailed molecular characterization of the interactions between $\mathrm{Rb}, \mathrm{C} / \mathrm{EBPs}$, and E2F-1. Rb may use subtly different motifs for interaction with the two classes of molecules. Alternatively, the binding of $\mathrm{Rb}$ to given transcription factors may alter their conformations and expose inherent elements remote from $\mathrm{Rb}$-binding sites. Altered conformations after interaction with $\mathrm{Rb}$ may then result in the binding of each transcription factor to different downstream target proteins and DNA sequences.

Other members of $\mathrm{Rb}$ protein family such as $\mathrm{p} 107$ and pl30 (Ewen et al. 1991; Li et al. 1993) could play similar roles in differentiation of cell types other than the few observed to be grossly abnormal in $R B^{-1-}$ embryos. Our preliminary data suggest that these other proteins have similar chaperone-like activities in C/EBP EMSA assays. Because the developmental expression patterns of p107 and p130 in mice (G. Chen et al. 1996) are quite different from that of $\mathrm{Rb}$ (Szekely et al. 1992), distinct but related roles for $\mathrm{Rb}, \mathrm{p} 107$, and $\mathrm{pl} 30$ in the acquisition of specific, differentiated cell phenotypes should be expected. Further studies in the differentiation of fibroblasts to adipocytes and in other model systems of cellular differentiation will be helpful in exploring such roles.

\section{Materials and methods}

Mouse embryonic lung fibroblasts and culture conditions

$\mathrm{C} 57 \mathrm{BL} / 6 \mathrm{~J} / 129 \mathrm{~Sv}$ mice heterozygous for an $R B$ gene disrupted at exon 20 (Lee et al. 1992) were crossed. On postcoital day 14.5, pregnant females were sacrificed. Lung buds were dissected individually from harvested embryos, minced, and cultured in Dulbecco's modified Eagle medium (DMEM, GIBCO BRL, Life Technologies, Inc., Gaithersburg, Maryland) containing 10\% fetal calf serum (Hyclone, Logan, UT). Cells propagated en masse under identical conditions, with medium changes every 3 to 4 days, were genotyped using murine $R B$ and $N e O$ gene oligomers designed for PCR (Nikitin and Lee 1996).

\section{Hormone treatment and determination of terminal differentiation}

Fibroblasts were induced to differentiate as described previously by Student et al. (1980). This induction involved first growing cells to confluence, then at day 0 of the differentiation induction program exposing them to fresh DMEM containing $10 \%$ FBS, $1 \mu \mathrm{M}$ dexamethasone (DEX), $10 \mu \mathrm{M}$ forskolin, and $10 \mu \mathrm{g} / \mathrm{ml}$ insulin for $48 \mathrm{hr}$ to initiate adipogenesis. The medium was then replaced with DMEM containing $10 \%$ FBS and $10 \mu \mathrm{g} / \mathrm{ml}$ insulin, and cells were refed every other day until day 8 . To confirm the appearance of the adipogenic phenotype, particularly the accumulation of fat droplets in the cytoplasm, cells were fixed at particular time points in $3 \%$ glutaraldehyde/ 100 mM sodium phosphate (pH 7.4) and stained with Oil Red EGN (Preece 1972).

\section{RNA blotting analysis}

Total RNA was prepared from cells as described previously (Shan et al. 1992). For Northern blotting, $10 \mu \mathrm{g}$ of RNA from cells in each condition were used. cDNAs used as probes were those encoding 422/aP2 (Spiegelman et al. 1983) and G $\beta$-like protein (Shan et al. 1992).

\section{Expression of GST fusion proteins}

The C/EBP cDNAs were expressed as GST fusion proteins in bacteria as described previously for other fusions /Shan et al. 1992). To construct GST-C/EBP $\alpha$, the MSV-C/EBP $\alpha$ plasmid (Christy et al. 1991) was digested with HindIII and then partially digested with $N$ col. Blunt ends were created in the resultant 1939-bp insert, and the fragment was then subcloned into the SmaI site of pGEX-2T. GST-LAP was constructed in several steps. First, the 1-kb EcoRI-Nhel fragment containing the LAP coding sequence from MSV-LAP was inserted into pBSK, then cleaved with EcoRI and $X b a$ I to create pBSK-LAPR. pBSKLAPR was then digested with NotI, extended to create blunt ends, and engineered with an EcoRI linker to generate pBSKLAPR2. The 1-kb NcoI-EcoRI fragment from pBSK-LAPR2 was then inserted into pGEPKIII, a derivative of pGEX-2T, and finally cleaved with $N c O I$ and EcoRI to create pGST-LAP. To generate pGST-C/EBPס, BamHI-digested pGEX2T (a 218-bp 
BamHI-NcoI fragment generated by PCR) was inserted along with a 790-bp NcoI-BamIII fragment of MSV-C/EBP $\delta$ in a three-way ligation into the amino-terminal fragment of C/EBPo. Primers 4-1 (5'-CAAGGATCCATGAGCGCCGCGCTTTTC-3') and 4-2 (5'-TGGGCACGGCGGCCTGGAGTCAATGT-3') were used to generate the 218-bp PCR fragment; absence of base substitution errors was confirmed by DNA sequencing. All GST-C/EBP constructs were used to transform Escherichia coli strain BL21-LysS and express the GST fusion proteins. Preparation of GST fusion proteins and $\mathrm{Rb}$ mutant proteins from bacteria has been described (Chen et al. 1995b).

\section{Coimmunoprecipitation}

Nuclei from terminally differentiated or undifferentiated fibroblasts were first prepared and disrupted in Lysis 250 buffer by subjecting them to three freeze/thaw cycles (liquid nitrogen/ $\left.37^{\circ} \mathrm{C}\right)$ and clearing by centrifugation $(14,000 \mathrm{rpm}, 2 \mathrm{~min}$ at room temperature). The supernatant was diluted with equal volumes of lysis buffer (without $\mathrm{NaCl}$ ) and used for coimmunoprecipitation as described (P.-L. Chen et al. 1996). Briefly, to each clarified supernatant was added $1 \mu \mathrm{g}$ of rabbit polyclonal anti-Rb antibody $(0.47)$ or $5 \mu \mathrm{l}$ anti-C/EBP $\beta$ polyclonal (C-19, Santa Cruz Biotech. Santa Cruz, California) antibody. Antigens and antibodies were incubated together for $1 \mathrm{hr}$ before the addition of protein A-Sepharose beads $(80 \mu \mathrm{l})$. After another 1-hr incubation, the beads were collected and washed five times with lysis buffer containing $125 \mathrm{~mm} \mathrm{NaCl}$. Beads were then boiled in SDS loading buffer for immunoblotting analysis.

\section{Cell lysate preparation, in vitro binding assay, and Western blotting}

Extracts made either from $2 \times 10^{6}$ WR2E3 cells or from bacterial lysates were incubated with beads containing 2-3 $\mu$ g of GST or GST fusion proteins in Lysis 150 buffer (identical to Lysis 250 buffer except that it contains $150 \mathrm{mM} \mathrm{NaCl}$ ) for $30 \mathrm{~min}$ at room temperature. Complexes were washed extensively with Lysis 150 buffer and analyzed by Western blotting using the primary antibodies, anti-Rb (11D7) or anti-C/EBP $\beta$ (C-19) as described (Chen et al. 1995b).

\section{DNA EMSAs}

GST fusion proteins, including GST-LAP, GST-RBS, GSTRBH209 and GST-E2F-1, were prepared as described above. E2F100, which contains sequences with which both LAP and E2F-1 interact specifically, was labeled with $\left[\alpha-{ }^{32} \mathrm{P}\right] \mathrm{dCTP}$ and served as probe (P.-L. Chen et al. 1996). Unlabeled oligo DNA (5'-GGACGTCACATTGCACAATCTTAATAA-3') containing the wild-type $(\mathrm{Wt})$ recognition sequence of LAP was used at 100 -fold molar excess as a competitor, as was a mutant oligo DNA (5'-GGACGTCACACTACAAACTCTTAATAA-3') (Mt) which cannot be recognized by LAP. The binding reaction mixtures for the LAP-DNA complex contained $10 \mathrm{mM}$ HEPES $(\mathrm{pH}$ 7.9), $60 \mathrm{~mm} \mathrm{KCl}, 5 \mathrm{~mm}$ Tris at $\mathrm{pH} 7.0,0.1 \mathrm{~mm}$ EDTA, $10 \%$ glycerol, $5 \mathrm{~mm} \mathrm{MgCl}_{2}, 2 \mathrm{mM}$ DTT, $2 \mathrm{mg} / \mathrm{ml}$ bovine serum albumin (BSA), and $4 \mathrm{ng}{ }^{32} \mathrm{P}$-labeled probe. The binding reactions for the E2F-DNA complexes have been described previously (Shan et al. 1992), except that BSA $(2 \mathrm{mg} / \mathrm{ml}$ ) was included in the reactions here. Analysis of binding complexes was performed by electrophoresis on a $5 \%, 0.25 \times$ TBE polyacrylamide gel at $4^{\circ} \mathrm{C}$.

\section{Transfection and CAT assays}

The reporter construct, $\mathrm{pP}_{(\mathrm{D}) 9} \mathrm{CAT}$, used in the transient assays was a gift from C.P. Mueller (Queen's University, Kingston, Ontario, Canada). To generate pCMVLAP, an NcoI-BamHI fragment containing the LAP coding sequence was inserted into an engineered CMVNeoBam vector. The NcoI site corresponds to the position of the initiating methionine of LAP (Cao et al. 1991). The construction of plasmids pCMVNeoRB and pCMV NeoRBH209 has been described (P.-L. Chen et al. 1996). Transfections were carried out by conventional calcium phosphate/ DNA coprecipitation in $5 \times 10^{6}$ WERI-RB27 cells. The precipitates were removed $12 \mathrm{hr}$ after transfection and the cultures were refed with fresh medium containing $10 \mu \mathrm{g} / \mathrm{ml}$ regular insulin. The cells were collected after $48 \mathrm{hr}$ and CAT activity was determined as previously described (Shan et al. 1992).

\section{Lipofection and cloning of RB-reconstituted ELF7 cells}

Wild-type and $\mathrm{H} 209$ mutant RB were individually inserted into the tetracycline-controllable vector (pUHD10-3) (Gossen and Bujard 1992). The tTA gene of the regulatory plasmid (pUHD151) was inserted into a new plasmid, pCMV-hygro, which provides a hygromycin selection marker, to form pCHTV. About $2 \times 10^{6}$ ELF7 cells were either cotransfected with $1 \mu \mathrm{g} \mathrm{pCHTV}$ and $10 \mu \mathrm{g}$ pUHD10-3/RB (or $10 \mu \mathrm{g}$ pUHD10-3/RBH209) by lipofection (GibcoBRL, Gaithersburg, MD). The cultures were refed with medium containing $200 \mu \mathrm{g} / \mathrm{ml}$ hygromycin (Sigma), $24 \mathrm{hr}$ after lipofection. The cells were refed every $3-4$ days with medium containing hygromycin until distinct colonies formed. Drug-resistant colonies were isolated 3 weeks later and propagated into mass cultures.

\section{Acknowledgments}

We thank R.J. Christy for helpful discussions, as well as for providing the $422 / \mathrm{aP} 2$ cDNA probe and C/EBP expression constructs (MSV-C/EBP 3, MSV-LAP, and MSV-C/EBPS); A. Nikitin for the gifts of the ELF1 and ELF7 cells and the details of their preparation; and A. Flesken-Nikitin for technical help with PCR genotyping. Work was supported by grants from the National Institutes of Health (EY05758, CA58318) and the Council for Tobacco Research to W.-H.L. D.J.R. is the recipient of a Physician's Research Training Award from the American Cancer Society.

The publication costs of this article were defrayed in part by payment of page charges. This article must therefore be hereby marked "advertisement" in accordance with 18 USC section 1734 solely to indicate this fact.

\section{References}

Bignon, Y.-J., J.-Y. Shew, D. Rappole, S.L. Naylor, E.Y.-H.P. Lee, J. Schnier, and W.-H. Lee. 1990. A single Cys ${ }^{706}$ to Phe substitution in the retinoblastoma protein causes loss of binding to the SV40 T antigen. Cell Growth Differ. 1: 647-651.

Bookstein, R., J.-Y. Shew, P.-L. Chen, P. Scully, and W.-H. Lee. 1990. Suppression of the tumorigenicity of human prostate carcinoma cells by replacing a mutated RB gene. Science 247: 712-715.

Cao, Z., R.M. Umek, and S.L. McKnight. 1991. Regulated expression of three C/EBP isoforms during adipose conversion of 3T3-Ll cells. Genes \& Dev. 5: 1538-1552.

Chen, G., C.T. Guy, H-W. Chen, N-P. Hu, E.Y.-H.P. Lee, and W.-H. Lee. 1996. Molecular cloning and developmental expression of mouse p130, a member of the retinoblastoma 
gene family. J. Biol. Chem. 271: 9567-9572.

Chen, P.-L., D.J. Riley, and W.-H. Lee. 1995a. The retinoblastoma protein as a fundamental mediator of growth and differentiation signals. Crit. Rev. Eukaryotic Gene Expression 2: 79-95.

Chen, P.-L., Y.-C. Ueng, T. Durfee, K.-C. Chen, T. Yang-Feng, and W.-H. Lee. 1995b. Identification of a human homologue of yeast nuc2 which interacts with the retinoblastoma protein in a specific manner. Cell Growth Differ. 6: 199-210.

Chen, P.-L., D.J. Riley, S. Chen-Kiang, and W.-H. Lee. 1996. The retinoblastoma protein interacts with and activates NF-IL6. Proc. Natl. Acad. Sci. 93: 465-469.

Christy, R.J., V.W. Yang, J.M. Ntambi, D.E. Getman, W.H. Landschulz, A.D. Friedman, Y. Nakabeppu, T.T Kelly, and M.D. Lane. 1989. Differentiation-induced gene expression in 3T3-L1 preadipocytes: CCAAT/enhancer-binding protein interacts with and activates the promoters of two adipocyte specific genes. Genes \& Dev. 3: 1323-1335.

Christy, R.J., K.H. Kaestner, D.E. Geiman, and M.D. Lane. 1991. CCAAT/enhancer binding protein gene promoter: Binding of nuclear factors during differentiation of 3T3-L1 preadipocytes. Proc. Natl. Acad. Sci. 88: 2593-2597.

DeCaprio, J.A., J.W. Ludlow, J. Figge, J.-Y. Shew, C.-M. Huang, W.-H. Lee, E. Marsillo, E. Pauch, and D.M. Livingston. 1988. SV40 large tumor antigen forms a specific complex with the product of the retinoblastoma susceptibility gene. Cell 54: 275-283.

Descombes, P. and U. Schibler. 1991. A liver-enriched transcriptional activator protein, LAP, and a transcriptional inhibitory protein, LIP, are translated from the same mRNA. Cell 67: 569-579.

Durfee, T., M.A. Mancini, D. Jones, S.J. Elledge, and W.-H. Lee. 1994. The amino-terminal portion of the retinoblastoma gene product binds a novel nuclear matrix protein that colocalizes to centers for RNA processing. I. Cell Biol. 127: 609-622.

Ellis, R.J. and S.M. van der Vies. 1991. Molecular chaperones. Annu. Rev. Biochem. 60: 321-347.

Ewen, M.E., Y. Xing, J.B. Lawrence, and D.M. Livingston. 1991. Molecular cloning, chromosomal mapping, and expression of the cDNA for p107, a retinoblastoma gene product-related protein. Cell 66: 1155-1164.

Freytag, S.O., D.L. Paielli, and T.D. Gilbert. 1994. Ectopic expression of the CCAAT/enhancer-binding protein $\alpha$ promotes the adipogenic program in a variety of mouse fibroblastic cells. Genes \& Dev. 8: 1654-1663.

Goodrich, D.W., N.P. Wang, Y.-W. Qian, E.Y.-H.P. Lee, and W.H. Lee. 1991. The retinoblastoma gene product regulates progression through the Gl phase of the cell cycle. Cell 67: 293-302.

Gossen, M. and H. Bujard. 1992. Tight control of gene expression in mammalian cells by tetracycline-responsive promoters. Proc. Natl. Acad. Sci. 89: 5547-5551.

Green, H. and O. Keinde. 1974. Sublines of mouse 3T3 cells that accumulate lipid. Cell 1: 113-116.

Gu, W., J.W. Schneider, G. Condorelli, S. Kaushal, V. Mahdavi, and B. Nadal-Ginard. 1993. Interaction of myogenic factors and the retinoblastoma protein mediates muscle cell commitment and differentiation. Cell 72: 309-324.

Hensey, C.E., F. Hong, T. Durfee, Y.-W. Qian, E.Y.-H.P. Lee, and W.-H. Lee. 1994. Identification of discrete structural domains in the retinoblastoma protein: Amino-teminal domain is required for its oligomerization. J. Biol. Chem. 269: 1380-1387.

Hu, E., P. Tontotoz, and B.M. Spiegelman. 1995. Transdifferentiation of myoblasts by the adipogenic transcription factors
PPAR $\gamma$ and C/EBP $\alpha$. Proc. Natl. Acad. Sci. 92: 9856-9860.

$\mathrm{Hu}$, Q., N. Dyson, and E. Harlow. 1990. The regions of the retinoblastoma protein needed for binding to adenovirus E1A or SV40 large $\mathrm{T}$ antigen are common sites for mutations. $E M B O$ I. 9: 1147-1155.

Huang, H.-I.S., J.K. Yee, J.Y. Shew, P.-L. Chen, R. Bookstein, T. Friedmann, E.Y.-H.P. Lee, and W.-H. Lee. 1988. Suppression of the neoplastic phenotype by replacement of the RB gene in human cancer cells. Science 242: 1563-1566.

Huang, S., N.P. Wang, B.Y. Tseng, W.-H. Lee, and E.Y.-H.P. Lee. 1990. Two distinct and frequently mutated regions of the retinoblastoma protein are required for binding to SV40 T antigen. EMBO J. 9: 1815-1822.

Jacks, T., A. Fazeli, E.M. Schmitt, R.T. Bronson, M.A. Goodell, and R.A. Weinberg. 1992. Effects of an Rb mutation in the mouse. Nature 359: 295-300.

Johnson, D.G., J.K. Schwarz, W.D. Cress, and J.R. Nevins. 1993. Expression of transcription factor E2F-1 induces quiescent cells to enter S phase. Nature 365: 349-352.

Lee, E.Y.-H.P., C.-Y. Chang, N. Hu, Y.-C.J. Wang, C.-C. Lai, K. Herrup, W.-H. Lee, and A. Bradley. 1992. Mice deficient for $\mathrm{Rb}$ are nonviable and show defects in neurogenesis and haematopoiesis. Nature 359: 288-294.

Lee, E.Y.-H.P., N. Hu, S.-S.F. Yuan, L.A. Cox, A. Bradley, W.-H. Lee, and K. Herrup. 1994. Dual roles of the retinoblastoma protein in cell cycle regulation and neuron differentiation. Genes \& Dev. 8: 2008-2021.

Li, Y., C. Graham, S. Lacy, A. Duncan, and P. Whyte. 1993. The adenovirus E1A-associated pl30-kd protein is encoded by a member of the retinoblastoma gene family and physically interacts with cyclins A and E. Genes \& Dev. 7: 2366-2377.

Lin, F.-T. and M.D. Lane. 1994. CCAAT/enhancer-binding protein $\alpha$ is sufficient to initiate the 3T3-L1 adipocyte differentiation program. Proc. Natl. Acad. Sci. 91: 8757-8761.

McKnight, S.L., M.D. Lane, and S. Gluecksohn-Waelsch. 1989. Is CCAAT/enhancer-binding protein $\alpha$ central regulator of energy metabolism? Genes \& Dev. 3: 2021-2024.

Mueller, C.P., P. Maire, and U. Schibler. 1990. DBP, a liverenriched transcriptional activator, is expressed late in ontogeny and its tissue specificity is determined posttranscriptionally. Cell 61: 279-291.

Nikitin, A.Yu. and W.-H. Lee. 1996. Early loss of the retinoblastoma gene is associated with impaired growth-inhibitory innervation during melanotroph carcinogenesis in $R b+/-$ mice. Genes \& Dev. 10: 1870-1879.

Nevins, J.R. 1992. E2F: A link between the Rb tumor suppressor protein and viral oncoproteins. Science 258: 424-429.

Preece, A. 1972. Manual for histologic technicians, pp. 260, Little, Brown, and Co., Boston, Massachusetts.

Riley, D.J., E.Y.-H.P. Lee, and W.-H. Lee. 1994. The retinoblastoma protein: More than a tumor suppressor. Annu. Rev. Cell Biol. 10: 1-29.

Sager, R. and P. Kovac. 1982. Preadipocyte determination either by insulin or by 5 -azacytidine. Proc. Natl. Acad. Sci. 79: $480-484$.

Samuelsson, L., K. Stromberg, K. Vikma, G. Bjursell, and S. Enerback. 1991. The CCAAT/enhancer-binding protein and its role in adipocyte differentiation: Evidence for direct involvement in terminal adipocyte differentiation. EMBO $/$. 10: $3787-3793$.

Schneider, J.W., W. Gu, L. Zhu, V. Mahdavi, and B. NadalGinard. 1994. Reversal of terminal differentiation mediated by p107 in Rb-/ - muscle cells. Science 264: 1467-1471.

Shan, B. and W.-H. Lee. 1994. Deregulated expression of E2F-1 accelerates S phase entry and leads to apoptosis. Mol. Cell. Biol. 14: 8166-8173. 


\section{Chen et al.}

Shan, B., X. Zhu, P.-L. Chen, T. Durfee, Y. Yang, D. Sharp, and W.-H. Lee. 1992. Molecular cloning of the cellular genes encoding retinoblastoma-associated proteins: Identification of a gene with properties of the transcription factor E2F. Mol. Cell. Biol. 12: 5620-5631.

Shan, B., T. Durfee, and W.-H. Lee. 1996. Distruption of Rb/ E2F-1 interaction by single-point mutations in E2F-1 enhances $\mathrm{S}$ phase entry and apoptosis. Proc. Natl. Acad. Sci. 93: 679-684.

Spiegelman, B.M., M. Frank, and H. Green. 1983. Molecular cloning of mRNA from $3 \mathrm{~T} 3$ adipocytes. I. Biol. Chem. 258: 10083-10089.

Student, A.K., R.Y. Hsu, and M.D. Lane. 1980. Induction of fatty acid synthetase sytithesis in differentiating $3 \mathrm{~T} 3-\mathrm{Ll}$ preadipocytes. J. Biol. Chem. 255: 4745-4750.

Szekely, L., W.-Q. Jiang, F. Bulic-Jakus, A. Rosen, N. Ringertz, G. Klein, and K.G. Wima. 1992. Cell type and differentiation dependent heterogeneity in retinoblastoma protein expression in SCID mouse fetuses. Cell Growth Differ. 3: 149-156.

Tontotoz, P., E. Hu, R.A. Graves, A.I. Budavari, and B.M. Spiegelman. 1994a. mPPAR $\gamma$ : Tissue-specific regulator of an adipocyte enhancer. Genes \& Dev. 8: 1224-1234.

Tontotoz, P., E. Hu, and B.M. Spiegelman. 1994b. Stimulation of adipogenesis in fibroblasts by PPAR $\gamma 2$, a lipid-activated transcription factor. Cell 79: 1147-1156.

Umek, R.M., A.D. Friedman, and S.L. McKnight. 1991. CCAAT/enhancer binding protein: A component of a differentiation switch. Science 251: 288-292.

Wang, N.-D., M.J. Finegold, A. Bradley, C.N. Ou, S.V. Abdelsayed, M.D. Wilde, C.R. Taylor, D.R. Wilson, and G.J. Darlington. 1995. Impaired energy homeostasis in $\mathrm{C} / \mathrm{EBP} \alpha$ knockout mice. Science 26: 1108-1112.

Whyte, P., K.J. Buchkovich, J.M. Horowitz, S.H. Friend, M. Raybuck, R.A. Weinberg, and E. Harlow. 1988. Association between an oncogene and an anti-oncogene: The adenovirus E1A protein binds to the retinoblastoma gene product. $\mathrm{Na}$ ture 334: 124-129.

Wu, Z., Y. Xie, N.L.R. Bucher, and S.R. Farmer. 1995. Conditional ectopic expression of C/EBP $\beta$ in NIH-3T3 cells induces PPAR $\gamma$ and stimulates adipogenesis. Genes \& Dev. 9: 2350-2363.

Yeh, W.-C., Z. Cao, M. Classon, and S.L. McKnight. 1995. Cascade regulation of terminal adipocyte differentiation by three members of the C/EBP family of leucine zipper proteins. Genes \& Dev. 9: 168-181. 


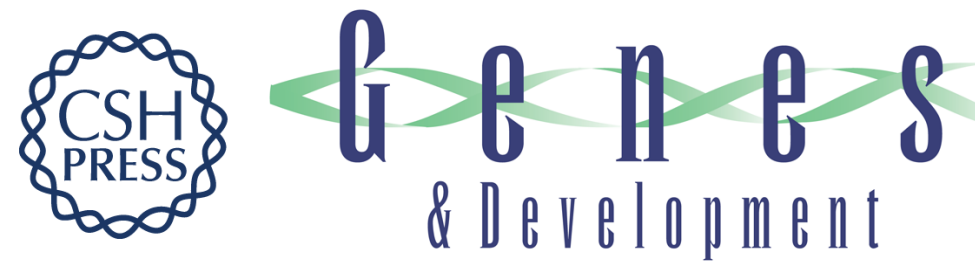

\section{Retinoblastoma protein positively regulates terminal adipocyte differentiation through direct interaction with C/EBPs.}

P L Chen, D J Riley, Y Chen, et al.

Genes Dev. 1996, 10:

Access the most recent version at doi:10.1101/gad.10.21.2794

References This article cites 51 articles, 32 of which can be accessed free at:

http://genesdev.cshlp.org/content/10/21/2794.full.html\#ref-list-1

License

Email Alerting

Service

Receive free email alerts when new articles cite this article - sign up in the box at the top right corner of the article or click here.

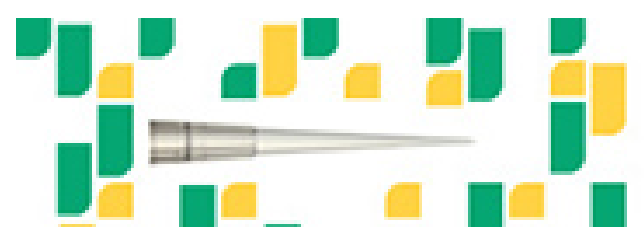

Focused on your science. 